\title{
Model Perkongsian Pengetahuan dalam Organisasi Sektor Swasta di Malaysia dan Hubungannya dengan Inovasi dan Prestasi Organisasi
}

\author{
Noorazah Md. Noor ${ }^{*}$, Juhana Salim ${ }^{b}$ \\ ${ }^{a}$ Fakulti Teknologi dan Sains Maklumat, Universiti Kebangsaan Malaysia, Bangi, Selangor \\ *Corresponding author: arekmn@yahoo.com
}

\section{Article history}

Received :17 January 2013

Received in revised form :

12 July 2013

Accepted :15 August 2013

\begin{abstract}
Knowledge sharing is the willingness of employee to contribute and the ability to collect knowledge from other employees within organization. Past studies found that successful knowledge sharing will enhance employee's innovation, and increase organizational performance. However, many factors influencing knowledge sharing such as human and technological factors. The aim of this research is to develop and validate the private sector knowledge sharing (PSKS) model incorporating two main approaches: technical and non technical. This research examines the influence of individual, organizational and technology on knowledge sharing and its relationship with innovation and organizational performance. Three theories supporting the development of PSKS model in order to examine the three factors are: Social Capital Theory, Institutional Theory and Adaptive Structuration Theory. This research used quantitative method with questionnaire technique and qualitative method with interview technique. Data were analyzed using SPSS for descriptive and demographic analysis, while model was validated using Structural Equation Modelling. This research found that individual influence; 'shared vision and goals' and 'trust between employees', organizational influence; 'task interdependence' and 'top management support' and technology influence; 'loyalty' in using knowledge management system influencing knowledge sharing practice. Further, knowledge sharing practice significantly relationship with innovation and innovation significantly related to organizational performance.
\end{abstract}

Keywords: Knowledge sharing; technical approach; non technical approach; innovation; organizational performance

\section{Abstrak}

Perkongsian pengetahuan merupakan kesediaan pekerja untuk menyumbang dan kemampuan beliau untuk mengumpul pengetahuan daripada pekerja lain dalam organisasi. Kajian lepas mendapati perkongsian pengetahuan yang berjaya akan menggalak inovasi pekerja dan meningkatkan prestasi organisasi. Namun, terdapat pelbagai halangan dalam perkongsian pengetahuan seperti faktor manusia dan teknologi. Matlamat kajian ini adalah untuk membina dan mengesahkan model perkongsian pengetahuan sektor swasta (MPS) yang menggabung dua pendekatan utama iaitu pendekatan teknikal dan bukan teknikal. Kajian ini bertujuan untuk memeriksa pengaruh individu, organisasi dan teknologi terhadap amalan perkongsian pengetahuan di kalangan pekerja serta hubungannya dengan inovasi dan prestasi organisasi. Tiga teori yang menyokong pembinaan model MPS bagi memeriksa tiga faktor pengaruh adalah Social Capital Theory, Institutional Theory dan Adaptive Structuration Theory. Kajian ini menggunakan kaedah kuantitatif dengan teknik soal selidik dan kaedah kualitatif dengan teknik temu bual. Data dianalisis menggunakan SPSS bagi analisis deskriptif dan demografi, manakala model disahkan mengguna Structural Equation Modelling. Kajian mendapati pengaruh individu; 'berkongsi visi dan matlamat' dan 'kepercayaan antara pekerja', pengaruh organisasi; 'tugas saling bergantungan' dan 'sokongan pengurusan atasan' dan pengaruh teknologi; 'kesetiaan' menggunakan sistem pengurusan pengetahuan mempengaruhi amalan perkongsian pengetahuan. Seterusnya, amalan perkongsian pengetahuan mempunyai hubungan yang signifikan dengan inovasi dan inovasi mempunyai hubungan yang signifikan ke atas prestasi organisasi.

Kata kunci: Perkongsian pengetahuan; pendekatan teknikal; pendekatan bukan teknikal; inovasi; prestasi organisasi 


\subsection{PENGENALAN}

“Pengetahuan', satu isu yang kerap dibincangkan kerana keupayaannya yang mampu mengubah pekerja dan organisasi. Pekerja yang berpengetahuan tinggi akan memperoleh ganjaran, pengiktirafan dan disanjung berbanding rakan yang kurang ilmu pengetahuannya. Manakala, organisasi yang dapat mengenalpasti, menilai dan menghasilkan pengetahuan akan berjaya. Menurut Johnson et al. (2005), pengetahuan didefinisikan sebagai "kesedaran, keinsafan atau kebiasaan yang diperoleh melalui pengalaman atau pembelajaran”. Pengetahuan ini termasuklah pengetahuan spesifik ataupun kombinasi pengetahuan melalui satu pembelajaran, latihan, pemerhatian dan pengalaman kerja terdahulu.

Hari ini, pengetahuan telah diterima dengan meluas dan dikenalipasti sebagai salah satu cara untuk meningkatkan daya saing sesebuah organisasi (Chan dan Chau, 2008). Kejayaan sesebuah negara atau masyarakat banyak bergantung kepada keupayaannya menggunakan segala sumber dengan baik termasuklah sumber intelektual rakyatnya iaitu pengetahuan. Bagi memastikan pengetahuan kekal dalam organisasi mesipun pemiliknya sudah tiada, perkongsian pengetahuan adalah satu jalan terbaik. Menurut Wang et al. (2000), pengetahuan yang dikongsi, diaplikasi dan diperbaharui dapat menjana idea kreatif.

Perkongsian pengetahuan merupakan kesediaan pekerja untuk menyumbang pengetahuan kepada pekerja lain dan kemampuan beliau untuk mengumpul pengetahuan daripada pekerja lain dalam organisasi. Perkongsian pengetahuan membolehkan pekerja menyelesaikan sesuatu masalah, mengurangkan kos yang bertindih dan membolehkan penciptaan satu inovasi yang baru. Kajian lepas mendapati amalan perkongsian pengetahuan yang berjaya akan menggalak inovasi pekerja dan meningkatkan prestasi organisasi (Yu, Yanfei dan Hailin, 2007). Walau bagaimanapun terdapat pelbagai faktor yang mempengaruhi perkongsian pengetahuan, antaranya adalah faktor manusia, organisasi dan teknologi.

\subsection{LATAR BELAKANG KAJIAN}

Kajian mengenai pengurusan pengetahuan telah banyak dibincangkan oleh ahli akademik mahupun pengamalnya (Syed Ikhsan dan Rowland, 2004), namun tidak banyak kajian yang khusus dalam perkongsian pengetahuan (Mohd Bakhari, 2010). Di Malaysia, kajian perkongsian pengetahuan lebih tertumpu kepada perkongsian pengetahuan dalam organisasi sektor awam berbanding kajian perkongsian pengetahuan dalam organisasi sektor swasta seperti ditunjukkan dalam Jadual 1.

Meskipun telah terbukti perkongsian pengetahuan banyak mendatangkan faedah sama ada kepada individu mahupun organisasi (Gibbert dan Krause, 2002), namun untuk mengajak manusia berkongsi pengetahuan adalah satu kerja berat (Skyrme, 2002). Oleh itu, ramai pengkaji memfokuskan kajian kepada faktor yang mempengaruhi perkongsian pengetahuan (Low et al. 2000; Lee dan Al-Hawamdeh, 2002; Lodhi, 2005; Riege, 2005; Norizah, et al. 2005; Ahmad, Shahrom dan Abdullah, 2006; Mohd Bakhari dan Zawiyah, 2008). Namun, faktor yang dikaji terlalu umum. Contohnya individu, kumpulan, struktur organisasi, budaya organisasi, teknologi, komunikasi, sumber manusia, ganjaran, kepercayaan dan arahan daripada ahli politik. Sedangkan menurut Sveiby (2001), perkongsian pengetahuan yang menyeluruh mesti melibatkan dua pendekatan utama iaitu pendekatan teknologi maklumat (IT) dan pendekatan sumber manusia.
Jadual 1 Kajian perkongsian pengetahuan dalam organisasi sektor awam dan dalam organisasi sektor swasta

\begin{tabular}{|c|c|c|}
\hline PENGKAJI & TAJUK KAJIAN & $\begin{array}{c}\text { SKOP } \\
\text { KAJIAN }\end{array}$ \\
\hline $\begin{array}{l}\text { Norizah et al. } \\
\text { (2005) }\end{array}$ & $\begin{array}{l}\text { Faktor yang } \text { Mempengaruhi } \\
\text { Perkongsian Pengetahuan di Tiga } \\
\text { Institusi Pengajian Tinggi di Malaysia } \\
\text { dan Kesannya ke atas Prestasi } \\
\text { Organisasi }\end{array}$ & AWAM \\
\hline $\begin{array}{l}\text { Hartini et al. } \\
\text { (2006) }\end{array}$ & $\begin{array}{l}\text { Perkongsian Pengetahuan dalam } \\
\text { Sektor Awam daripada Perspektif } \\
\text { Pengurusan Proses Perniagaan }\end{array}$ & AWAM \\
\hline $\begin{array}{l}\text { Zuliana dan } \\
\text { Khalil (2008) }\end{array}$ & $\begin{array}{l}\text { Hubungan Budaya Organisasi dengan } \\
\text { Perkongsian Pengetahuan }\end{array}$ & AWAM \\
\hline $\begin{array}{l}\text { Ling et al. } \\
(2009)\end{array}$ & $\begin{array}{l}\text { Perkongsian Pengetahuan dalam } \\
\text { Syarikat Multinasional Amerika yang } \\
\text { Berpangkalan di Malaysia }\end{array}$ & SWASTA \\
\hline $\begin{array}{l}\text { Mohamed } \\
\text { dan Egbu } \\
(2009)\end{array}$ & $\begin{array}{l}\text { Isu yang Dikaitkan dengan Inisiatif } \\
\text { Perkongsian Pengetahuan dalam } \\
\text { Agensi Kerajaan di Malaysia }\end{array}$ & AWAM \\
\hline $\begin{array}{l}\text { Mohd } \\
\text { Bakhari } \\
(2010)\end{array}$ & $\begin{array}{lr}\text { Model Kualiti } & \text { Perkongsian } \\
\text { Pengetahuan dalam } & \text { Organisasi } \\
\text { Awam dan Kesannya ke atas Prestasi } \\
\text { Pekerja serta } & \text { Penyampaian } \\
\text { Perkhidmatan } & \end{array}$ & AWAM \\
\hline $\begin{array}{l}\text { Suppiah dan } \\
\text { Sandhu } \\
\text { (2011) }\end{array}$ & $\begin{array}{l}\text { Pengaruh Budaya } \text { Organisasi ke atas } \\
\text { Tingkah laku } \\
\text { Pengetahuan Tasit }\end{array}$ & SWASTA \\
\hline $\begin{array}{l}\text { Nurliza et al. } \\
\text { (2011) }\end{array}$ & $\begin{array}{l}\text { Penentu Utama Perkongsian } \\
\text { Pengetahuan dalam Firma Pembuatan } \\
\text { Elektronik di Malaysia }\end{array}$ & SWASTA \\
\hline $\begin{array}{l}\text { Sandhu et al. } \\
\text { (2011) }\end{array}$ & $\begin{array}{lrr}\text { Perkongsian } & \text { Pengetahuan } & \text { di } \\
\text { Kalangan } & \text { Pekerja } & \text { Sektor } \\
\text { Awam:Bukti dari Malaysia } & \end{array}$ & AWAM \\
\hline
\end{tabular}

Beberapa kajian telah menyediakan bukti jelas tentang pentingnya peranan perkongsian pengetahuan dan keupayaan inovasi untuk prestasi organisasi (Andrew et al. 2001). Ini bermakna, tahap kesediaan seseorang individu untuk berkongsi pengetahuan bukan sahaja akan meningkatkan pertukaran pengetahuan, tetapi juga akan mengurangkan kelikatan pengetahuan dalam organisasi dan meningkatkan inovasi. Hall (2002), menyatakan bahawa sikap dan kesediaan individu untuk berkongsi pengetahuan diakui sebagai faktor penting untuk inovasi organisasi. Seterusnya, inovasi memberi kesan terhadap prestasi organisasi (Yu, Yanfei dan Hailin, 2007).

Dalam kajian perkongsian pengetahuan, tedapat banyak teori yang telah diaplikasikan dalam penyelidikan seperti Social Exchange Theory (SET), Social Capital Theory (SCT), Social Cognitive Theory (SCT), Expectency Theory (ET), Theory of Reasoned Action (TRA) dan Theory of Planned Behaviour (TPB) (Liang et al. 2008). Walau bagaimanapun, kebanyakan kajian hanya fokus kepada satu teori sahaja yang menjurus kepada faktor yang dikaji. Contohnya, TRA, TPB dan SCT bagi mengkaji faktor individu manakala SET bagi mengkaji faktor organisasi (Mohd Bakhari, 2010). 


\subsection{TINJAUAN LITERATUR}

\subsection{Perkongsian Pengetahuan}

Perkongsian pengetahuan adalah proses di mana "satu sumber diberi oleh satu pihak dan diterima oleh satu pihak yang lain" (Sharratt dan Usoro, 2003). Perkongsian pengetahuan juga dikenali sebagai pemindahan pengetahuan yang bermaksud berkongsi pengetahuan di antara individu dan kumpulan dalam satu perusahaan. Perkongsian pengetahuan hanya akan berlaku apabila seseorang individu benar-benar berminat untuk menolong orang lain bagi membangunkan kemampuan untuk satu tindakalan (Disterer, 2001). Perkongsian pengetahuan melibatkan proses dua hala iaitu menyumbang pengetahuan kepada rakan dan mengumpul pengetahuan daripada rakan dalam organisasi. Dalam kajian ini, perkongsian pengetahuan merujuk kepada kesediaan seorang pekerja untuk menyumbang pengetahuan tasit dan pengetahuan eksplisit kepada pekerja lain dan kemampuan beliau untuk mengumpul pengetahuan tasit dan pengetahuan eksplisit daripada pekerja lain dalam organisasi.

Perkongsian pengetahuan banyak mendatangkan faedah sama ada kepada individu mahupun organisasi seperti menjimatkan masa pekerja dan majikan (Gibbert dan Krause, 2002). Zhang et al. (2006), dalam kajiannya telah meringkaskan beberapa manfaat perkongsian pengetahuan seperti mengurangkan kesilapan, mempercepatkan penyelesaian masalah, mempercepatkan proses pembelajaran, mengurangkan kos pengumpulan pengetahuan dalam organisasi, menukar kelebihan individu kepada kelebihan organisasi dan mengurangkan kebergantungan organisasi kepada individu sekiranya mereka berpindah atau bertukar tempat kerja. Namun, untuk mengajak individu berkongsi pengetahuan bukanlah satu kerja mudah. Justeru, banyak model perkongsian pengetahuan terdahulu lebih tertumpu kepada faktor yang mempengaruhi perkongsian pengetahuan.

\subsection{Model Perkongsian Pengetahuan Terdahulu}

Model adalah perwakilan realiti. Model boleh digunakan untuk meningkatkan pemahaman tentang faktor yang mempengaruhi perkongsian pengetahuan dalam organisasi. Model yang berkaitan dengan perkongsian pengetahuan termasuklah SECI Model (Nonaka dan Takeuchi, 1995), Model for Best Practice (O'Dell dan Grayson, 1998), Knowledge Transfer Model (Inkpen dan Dinur, 1998), Organizational Knowledge Sharing Model (Wang, 1999) dan Culture Based Knowledge Sharing Model (Lodhi, 2005). Dalam kajian ini, penyelidik menganalisis lima model perkongsian pengetahuan terdahulu yang dilaksanakan dalam organisasi sektor swasta bagi menghasilkan konstruk yang relevan untuk membangunkan model yang sepatutnya dan sempurna. Di antara kajian tersebut adalah Perkongsian Pengetahuan Dalam Institusi Pengajian Tinggi, Persepektif dari Malaysia (M.Sadiq dan Salina, 2009), Penentu Utama Perkongsian Pengetahuan Dalam Firma Pembuatan Elektronik di Malaysia (Nurliza et al. 2010), Amalan Perkongsian Pengetahuan Sebagai Faktor Mudah Untuk Meningkatkan Prestasi Organisasi Melalui Modal Insan: Satu Kajian Awal (Hsu, 2008), Kajian Tentang Faktor Yang Mempengaruhi Aktiviti Perkongsian Pengetahuan Untuk Aktiviti Inovasi Kumpulan (Lee et al. 2010) dan Memahami Keinginan Berkongsi Pengetahuan Profesional IT Melalui Penggunaan Knowledge Managent System (KMS): Perspektif Teori Pertukaran Sosial (Social Exchange Theory) (Tsai et al. 2012). Ringkasan bagi lima model perkongsian pengetahuan yang dikaji adalah seperti ditunjukkan dalam Jadual 2.

Jadual 2 Ringkasan model perkongsian pengetahuan terdahulu

\begin{tabular}{|c|c|c|c|}
\hline Pengkaji & $\begin{array}{l}\text { Faktor Yang Mempengaruhi Perkongsian } \\
\text { Pengetahuan }\end{array}$ & Teori & Hasil Organisasi \\
\hline M.Sadiq dan Salina (2009) & $\begin{array}{l}\text { - Sifat pengetahuan } \\
\text { - Budaya kerja } \\
\text { - Sikap kakitangan } \\
\text { - Motivasi untuk berkongsi } \\
\text { - Peluang untuk berkongsi }\end{array}$ & Tiada & Tiada \\
\hline Nurliza et al. (2011) & $\begin{array}{l}\text { - Individualisme } \\
\text { - Kolektivisme } \\
\text { - Rangkaian sosial } \\
\text { - Kepercayaan } \\
\text { - Berkongsi matlamat } \\
\text { - Sistem insentif } \\
\text { - Keberkesanan diri } \\
\text { - Kiasuism }\end{array}$ & Tiada & Tiada \\
\hline Hsu (2008) & $\begin{array}{l}\text { - Nilai pengetahuan pengurusan atasan } \\
\text { - Strategi inovasi } \\
\text { - Modal insan organisasi }\end{array}$ & $\begin{array}{l}\text { Resource-Based View } \\
\text { of the Firm (RBV) }\end{array}$ & Prestasi organisasi \\
\hline Lee et al. (2010) & $\begin{array}{l}\text { Faktor Personal } \\
\text { - Keseronokan berkongsi pengetahuan } \\
\text { - Keberkesanan diri } \\
\text { Faktor Organisasi } \\
\text { - Sokongan eksekutif } \\
\text { - Ganjaran organisasi } \\
\text { Faktor Teknikal } \\
\text { - Penggunaan sistem }\end{array}$ & Tiada & Inovasi \\
\hline
\end{tabular}




\begin{tabular}{|c|c|c|c|}
\hline Pengkaji & $\begin{array}{l}\text { Faktor Yang Mempengaruhi Perkongsian } \\
\text { Pengetahuan }\end{array}$ & Teori & Hasil Organisasi \\
\hline \multirow[t]{2}{*}{ Tsai et al. (2012) } & $\begin{array}{l}\text { Teori Pertukaran Sosial } \\
\text { - } \quad \text { Sokongan organisasi } \\
\text { - } \quad \text { Kepercayaan organisasi } \\
\text { - Hubungan dua hala } \\
\text { Keberkesanan diri }\end{array}$ & $\begin{array}{l}\text { Social Exchange Teory } \\
\text { (SET) }\end{array}$ & Tiada \\
\hline & $\begin{array}{l}\text { Sikap terhadap penggunaan } \\
\text { Management System (KMS) }\end{array}$ & & \\
\hline
\end{tabular}

Berdasarkan Jadual 1, semua lima kajian memberi fokus kepada hubungan antara faktor yang mempengaruhi dengan perkongsian pengetahuan. Faktor yang kerap dikaji adalah berkenaan individu (pekerja) seperti sikap kakitangan (M.Sadiq dan Salina, 2009), modal insan organisasi (Hsu 2008) dan keberkesanan diri (Nurliza, et al. 2011; Lee et al. 2010; Tsai et al. 2012). Seterusnya, faktor berkaitan organisasi seperti budaya kerja (M.Sadiq dan Salina, 2009), sistem insentif dan ganjaran organisasi (Nurliza et al. 2011; Lee et al. 2010) dan sokongan eksekutif, sokongan organisasi dan kepercayaan organisasi (Lee et al. 2010; Tsai et al. 2012). Manakala, dua daripada lima kajian turut mengkaji tentang faktor teknologi seperti penggunaan sistem dan sikap pengguna terhadap penggunaan KMS (Lee et al. 2010; Tsai et al. 2012). Dapatan ini menunjukkan bahawa individu, organisasi dan teknologi adalah tiga faktor yang sangat mempengaruhi perkongsian pengetahuan di kalangan pekerja dalam sebuah organisasi.

Hasil analisis juga mendapati bahawa beberapa kajian mengaitkan faktor yang mempengaruhi perkongsian pengetahuan dengan hasil organisasi seperti inovasi (Lee et al. 2010) dan prestasi organisasi (Hsu, 2008). Namun, kedua-dua pengkaji hanya memeriksa satu daripada hasil organisasi sama ada inovasi ataupun prestasi organisasi secara berasingan tanpa menggabungkan keduaduanya sekali dalam sebuah model. Selain itu, dua daripada lima kajian turut mengaplikasikan teori dalam kajian perkongsian pengetahuan (Hsu, 2008 dan Tsai et al. 2012), manakala selebihnya tidak merujuk kepada mana-mana teori dalam penyelidikan. Teori yang digunakan juga hanya fokus kepada satu teori sahaja yang berkaitan dengan faktor yang dikaji.

Oleh yang demikian, objektif kajian ini adalah untuk membangunkan sebuah model perkongsian pengetahuan di kalangan pekerja dalam organisasi sektor swasta di Malaysia yang menyeluruh dengan menggabungkan pendekatan IT/teknikal (PT) iaitu pengaruh teknologi dan pendekatan sumber manusia/ bukan teknikal (PBT) yang merujuk kepada pengaruh individu dan pengaruh organisasi. Tiga teori yang berkaitan dengan perkongsian pengetahuan iaitu Teori Modal Sosial (Social Capital TheorySCT), Teori Institusi (Institutional Theory-INT) dan Teori Strukturasi Adaptif (Adaptive Structuration Theory-AST) digabung dan diaplikasikan dalam kajian bagi mengkaji pengaruh individu, organisasi dan teknologi. Seterusnya, memeriksa kesan amalan perkongsian di kalangan pekerja ke atas inovasi dan prestasi organisasi secara serentak dalam sebuah model bersepadu.

\subsection{Model Perkongsian Pengetahuan Sektor Swasta}

Meskipun perkongsian pengetahuan dalam sebuah organisasi dipengaruhi oleh pelbagai kriteria, namun kajian ini hanya fokus kepada tiga faktor pengaruh yang sangat mempengaruhi amalan perkongsian pengetahuan di kalangan pekerja dalam sebuah organisasi iaitu individu, organisasi dan teknologi yang dikategorikan kepada dua pendekatan utama iaitu PT dan PBT. PT merujuk kepada pengaruh teknologi, manakala PBT merujuk kepada pengaruh individu dan pengaruh organisasi. Bagi memeriksa tiga faktor pengaruh, tiga teori diaplikasikan dalam kajian iaitu SCT bagi memeriksa pengaruh individu, INT bagi memeriksa pengaruh organisasi dan AST bagi memeriksa pengaruh teknologi.

\section{(1) Pendekatan Teknikal}

Pendekatan teknikal (PT) merujuk kepada pengaruh teknologi iaitu keupayaan yang disediakan oleh teknologi maklumat untuk organisasi berkongsi pengetahuan. Teknologi menyediakan dua keupayaan dalam perkongsian pengetahuan; mengintegrasikan pengetahuan dan menyediakan rangkaian. Menurut Fan et al. (2008), teknologi mempunyai hubungan yang signifikan dalam meningkatkan keupayaan perkongsian dalam organisasi. Teori Strukturasi Adaptif (Adaptive Structuration Theory-AST) diadaptasikan dalam kajian ini bagi mengkaji pengaruh teknologi. AST mula popular apabila IT menjadi komponen penting dalam organisasi dan diaplikasikan dalam kajian sistem maklumat (IS) (Orlikowski dan Robey, 1991; Chatterjee et al. 2002, DeSanctis dan Poole, 1994, Salisbury et al. 2002; Chin et al. 1997). AST menekankan kepada interaksi antara kumpulan dalam organisasi dengan teknologi dan bagaimana teknologi boleh membantu dalam aktiviti kerja seharian. Dalam kajian ini, pengaruh teknologi merujuk kepada penggunaan sistem pengurusan pengetahuan (Knowledge Management System-KMS) untuk meningkatkan perkongsian pengetahuan di kalangan pekerja dalam organisasi seperti Ms SharePoint, Lotus Note dan KM Portal. Oleh itu, hipotesis yang dicadangkan adalah:

\section{$H_{1}$ : Pengaruh teknologi secara positif mempengaruhi amalan perkongsian pengetahuan di kalangan pekerja dalam organisasi sektor swasta di Malaysia.}

KMS dibentuk oleh satu kelas IT, direka untuk membuatkan pengetahuan tersedia, memobilisasi aliran pengetahuan dan dengan demikian akan memudahkan pengguna untuk secara proaktif mencari dan menawarkan pengetahuan (Alavi dan Leidner, 2001). Kajian terdahulu menunjukkan bahawa kesetiaan terhadap penggunaan teknologi canggih seperti sistem mesyuarat elektroknik (Electronic Meeting System-EMS) dan sistem sokongan keputusan kumpulan (Group Decison Support SystemGDSS) akan meningkatkan proses dan hasil (Chin et al. 1997; DeSanctis dan Poole, 1994). Kajian oleh Yu dan Khalifa (2007), juga mengesahkan bahawa kesetiaan kepada penggunaan KMS mempunyai kesan positif ke atas perkongsian pengtahuan di antara kumpulan. Konsensus atau persetujuan sebulat suara ahli kumpulan untuk menggunakan KMS dalam pekerjaan mereka juga mempengaruhi perkongsian pengetahuan (DeSanctis dan Poole, 1994). Dengan menggunakan EMS sebagai sampel kajian, Salisbury et al. (2002) mendapati bahawa konsensus terhadap penggunaan sistem mempengaruhi keputusan yang diharapkan. Selain itu, sikap individu terhadap teknologi termasuklah penerimaan dan 'rasa mudah untuk menggunakan sistem' sangat mempengaruhi penggunaan sesuatu teknologi (Davis, 1989). 
Kajian oleh Yu dan Khalifa (2007), mengesahkan dapatan ini apabila mendapati sikap individu terhadap penggunaan KMS mempengaruhi perkongsian pengetahuan dalam kumpulan. Berdasarkan dapatan ini, hipotesis yang dicadangkan adalah:

$H_{1 a}:$ Kesetiaan individu menggunakan KMS secara positif mempengaruhi amalan perkongsian pengetahuan di kalangan pekerja dalam organisasi sektor swasta di Malaysia.

$H_{1 b}$ : Konsensus terhadap penggunaan KMS secara positif mempengaruhi amalan perkongsian pengetahuan di kalangan pekerja dalam organisasi sektor swasta di Malaysia.

$H_{1 c}:$ Sikap individu terhadap penggunaan KMS secara positif mempengaruhi amalan perkongsian pengetahuan di kalangan pekerja dalam organisasi sektor swasta di Malaysia.

\section{(2) Pendekatan Bukan Teknikal}

Pendekatan bukan teknikal (PBT) adalah keadaan susun atur institusi, mekanisma insentif dan budaya, yang menyediakan perkhidmatan kepada perkongsian pengetahuan organisasi (Fan et al. 2008). PBT juga merujuk kepada "persekitaran lembut" yang menyokong perkongsian pengetahuan dalam organisasi. Dalam kajian ini, pengaruh individu dan pengaruh organisasi diklasifikasikan sebagai PBT. Kedua-duanya penting kerana jika sebuah organisasi menghabiskan banyak wang untuk membeli peralatan IT, tetapi tanpa susunan institusi, mekanisme insentif dan budaya yang betul, kecekapan penggunaan peralatan IT tidak berkesan dan perkongsian pengetahuan organisasi menjadi tidak kukuh (Fan et al. 2008).

Individu (pekerja) adalah nadi bagi amalan perkongsian pengetahuan dalam sebuah organisasi. Individu bertanggungjawab untuk mewujud dan berkongsi pengetahuan (Lee dan Choi, 2003). Walaupun kecanggihan IT dan rangkaian komputer telah memudahkan perkongsian pengetahuan, tetapi tanpa individu pengetahuan tidak akan dicipta dalam organisasi (Coleman, 1999). Teori Modal Sosial (Social Capital Theory-SCT) adalah teori yang menekankan hubungan antara individu, kumpulan atau organisasi dan perkongsian pengetahuan (Burt, 1992; Coleman, 1990; Nahapiet dan Ghoshal, 1998; Adler dan Kwon, 2002). SCT menyediakan syarat yang diperlukan untuk perkongsian dan pemindahan pengetahuan berlaku (Nahapiet dan Ghoshal, 1998). Secara empirikal, SCT telah terbukti mampu mempengaruhi individu untuk menyumbang pengetahuan mereka dalam komuniti sosial (Wasko dan Faraj, 2005) atau dalam organisasi (Kankanhalli et al. 2005). Oleh itu, hipotesis yang dicadangkan adalah:

\section{$\mathrm{H}_{2}$ : Pengaruh individu secara positif mempengaruhi amalan perkongsian pengetahuan di kalangan pekerja dalam organisasi sektor swasta di Malaysia.}

SCT menyatakan bahawa perkongsian pengetahuan akan menjadi lebih mudah apabila (Nahapiet dan Ghoshal 1998);

- $\quad$ ada hubungan struktural di antara individu (structural capital);

- $\quad$ individu memiliki kemampuan kognitif untuk memahami dan melaksanakan pengetahuan (cognitive capital), dan

- hubungan di antara individu mempunyai ciri yang kuat dan positif (relational capital)

Dalam kajian ini, tiga pemboleh ubah bagi pengaruh individu iaitu rangkaian sosial, berkongsi visi dan matlamat organisasi dan kepercayaan antara pekerja adalah berdasarkan kepada tiga komponen yang terdapat dalam SCT iaitu modal struktur (structural capital), modal kognitif (cognitive capital) dan modal hubungan (relational capital). Rangkaian sosial merujuk kepada komunikasi, dialog dan interaksi individu dan kumpulan yang menyokong dan menggalakkan aktiviti berkaitan pengetahuan pekerja (Leonard 1995, Lavinthal dan March 1993). Hubungan antara individu dalam rangkaian sosial memudahkan pemindahan pengetahuan dan meningkatkan perkongsian pengetahuan. Berkongsi visi dan matlamat organisasi yang sama mampu menyatukan pekerja untuk berkongsi pengetahuan. Menurut Wasko dan Faraj (2005), perkongsian pengetahuan memerlukan pemahaman bersama. Dengan satu visi dan matlamat organisasi yang jelas dan dikongsi bersama akan menimbulkan satu perasaan penglibatan dan sumbangan di kalangan pekerja untuk membantu rakan lain dalam organisasi serta meningkatkan perkongsian pengetahuan. Kepercayaan antara pekerja membolehkan perkongsian pengetahuan berlaku dengan spontan dan cekap (Chowdhury 2005). Kajian empirikal oleh Roberts (2000) dan Zand (1972), mendapati ada hubungan yang signifikan di antara kepercayaan pekerja dan perkongsian pengetahuan. Berdasarkan dapatan ini, hipotesis yang dicadangkan adalah:

$H_{2 a}$ : Rangkaian sosial antara pekerja secara positif mempengaruhi amalan perkongsian pengetahuan di kalangan pekerja dalam organisasi sektor swasta di Malaysia.

$\mathrm{H}_{2 b}$ : Berkongsi visi dan matlamat organisasi secara positif mempengaruhi amalan perkongsian pengetahuan di kalangan pekerja dalam organisasi sektor swasta di Malaysia.

$\mathrm{H}_{2 c}$ : Kepercayaan antara pekerja secara positif mempengaruhi amalan perkongsian pengetahuan di kalangan pekerja dalam organisasi sektor swasta di Malaysia.

Organisasi adalah entiti sosial, dimana budaya bertindak sebagai pelekat (glue) yang menyatukan individu dalam satu struktur sosial (Smircich, 1983), dan memegang sebahagian daripada pengetahuan kolektif dan pengetahuan tersirat organisasi serta membentuk rutin dan cara perlakuan dalam organisasi. Organisasi membolehkan pengetahuan ditawan, diurus, digunakan semula dan dipindahkan di kalangan pekerja serta membuatkan ianya tersedia untuk pekerja lain dalam perniagaan.

Perkongsian pengetahuan dalam organisasi membantu rakan sekerja melakukan suatu kerja dengan lebih baik, lebih cepat dan lebih cekap (Lin, 2007). Dalam kajian ini, Teori Institusi (Institutional Theory-INT) dipilih untuk menjelaskan pengaruh organisasi kerana teori ini memberi tumpuan yang lebih mendalam terhadap struktur sosial dalam organisasi. Struktur sosial adalah kumpulan kerja yang bersarang dalam organisasi dan mereka ini mampu mempengaruhi tindakan individu dalam tiga cara;

- Dominasi - struktur kumpulan yang ditentukan untuk mengawasi pengetahuan tak simetri yang dihasilkan daripada saling bergantungan.

- $\quad$ Signifikasi - struktur kumpulan yang ditentukan oleh skim interpretif (bertafsir). Individu melihat isyarat ini dan berinterpretasi, sama ada daripada pemimpin kumpulan atau daripada kumpulan lain atau pengurusan atasan sebagai panduan kognitif untuk memahami bagaimana mereka harus berkelakuan terhadap perkongsian pengetahuan.

- Legitimasi - struktur kumpulan yang ditentukan oleh tindakan dan perilaku individu. 
Tindakan ini disebut tindakan meta struktur, kerana ia sama ada akan menguatkan struktur institusi yang sedia ada atau mengubah struktur untuk mencipta keadaan yang lebih kondusif untuk berkongsi pengetahuan (Chatterjee et al. 2002). Oleh itu, hipotesis yang dicadangkan adalah:

\section{$H_{3}$ : Pengaruh organisasi secara positif mempengaruhi amalan perkongsian pengetahuan di kalangan pekerja dalam organisasi sektor swasta di Malaysia.}

Dalam kajian ini, tiga komponen penting dalam teori institusi iaitu dominasi, signifikasi dan legitimasi menjadi asas dalam pemilihan pemboleh ubah bagi memeriksa pengaruh organisasi. Pemboleh ubah bagi dominasi adalah tugas saling bergantungan. Tugas saling bergantungan merujuk kepada darjah tugas seseorang individu bergantung kepada usaha atau kemahiran orang lain (Wageman dan Baker, 1997). Kajian Yu dan Khalifa (2007), tentang perkongsian pengetahuan antara organisasi mendapati bahawa ahli dalam kumpulan yang mempunyai tahap tugas saling bergantungan yang tinggi akan terlibat dalam perkongsian pengetahuan dengan lebih kerap daripada ahli dalam kumpulan dengan tahap tugas saling bergantungan yang rendah. Signifikasi mengandungi pemboleh ubah sokongan pengurusan atasan. Sokongan pengurusan atasan dianggap sebagai salah satu pengaruh berpotensi yang penting kepada pengetahuan organisasi (Connelly dan Kelloway, 2003). Menurut Lin dan Lee (2004), sokongan pengurusan atasan dalam perkongsian pengetahuan diperlukan untuk mencipta dan mempertahankan budaya berkongsi pengetahuan yang positif dalam sebuah organisasi. Pemboleh ubah bagi legitimasi adalah budaya organisasi. Budaya organisasi merupakan cabaran terbesar dalam perkongsian pengetahuan. Ramai pengkaji mengakui budaya sangat penting dalam menjayakan perkongsian pengetahuan (Rubenstein-Montano et al. 2000) kerana 90 peratus kejayaannya bergantung kepada budaya dan manusia, manakala 10 peratus lagi adalah teknologi maklumat (Jarrar, 2002). Organisasi yang mengamalkan budaya kerjasama dan perkongsian lebih mudah menggalakkan perkongsian pengetahuan berbanding organisasi yang pekerjanya mengutamakan penyimpanan pengetahuan dan bersaing antara satu sama lain (Elliot dan O'Dell, 1999). Berdasarkan dapatan ini, hipotesis yang dicadangkan adalah:

\section{$\mathrm{H}_{3 a}$ : Tugas saling bergantungan antara pekerja secara positif mempengaruhi amalan perkongsian pengetahuan di kalangan pekerja dalam organisasi sektor swasta di Malaysia. \\ $\mathrm{H}_{3 b}$ : Sokongan pengurusan atasan secara positif mempengaruhi amalan perkongsian pengetahuan di kalangan pekerja dalam organisasi sektor swasta di Malaysia. \\ $H_{3 c}$ : Budaya organisasi secara positif mempengaruhi amalan perkongsian pengetahuan di kalangan pekerja dalam organisasi sektor swasta di Malaysia.}

\section{(3) Hubungan antara Perkongsian Pengetahuan Dengan Inovasi dan Prestasi Organisasi}

Kajian lepas menunjukkan bahawa perkongsian pengetahuan yang positif adalah prasyarat paling asas untuk inovasi (Hall, 2002; Liebowitz, 2003; Lin, 2007). Kapasiti dan kemampuan inovasi amat diperlukan untuk mempertingkatkan sumbangan kepada pembangunan ekonomi melalui penghasilan produk dan teknologi berteraskan pengetahuan (MOSTI, 2010). Menurut Song et al. (2008), kemampuan untuk mengeksploitasi pengetahuan dari luar adalah komponen penting dari kemampuan inovasi. Kemampuan ini secara kolektifnya akan membentuk apa yang disebut 'kapasiti menyerap' (absorptive capacity) dalam sebuah organisasi. Semakin tinggi daya serap sesebuah organisasi, semakin kuat kemampuan organisasi boleh berhubung dengan persekitaran luar, dan kebarangkalian yang lebih tinggi bagi organisasi untuk menggabungkan semula pengetahuan bagi mencipta pengetahuan baru. Berdasarkan dapatan ini, hipotesis yang dicadangkan adalah:

\section{$\mathrm{H}_{4}$ : Amalan Perkongsian pengetahuan di kalangan pekerja dalam organisasi sektor swasta di Malaysia secara positif mempengaruhi inovasi.}

Selain inovasi, kajian lepas juga menunjukkan bahawa perkongsian pengetahuan memberi kesan kepada prestasi sama ada prestasi pekerja mahupun prestasi organisasi. Oleh demikian, kebelakangan ini lebih banyak penyelidik memberi perhatian kepada pentingnya 'perkongsian pengetahuan' yang berkesan dan hubungannya dengan prestasi organisasi (Song et al. 2008). Mereka berpendapat bahawa budaya yang terlibat dan jenis rangkaian yang baik akan mempengaruhi perkongsian pengetahuan. Atas sebab itu, pengetahuan telah dianggap sebagai sumber paling kritikal dalam organisasi dan perkongsian pengetahuan adalah aktiviti penting yang menyumbang kepada pencapaian prestasi dan objektif organisasi (Lee et al. 2010). Berdasarkan dapatan ini, hipotesis yang dicadangkan adalah: $\mathrm{H}_{5}$ : Amalan Perkongsian pengetahuan di kalangan pekerja dalam

organisasi sektor swasta di Malaysia secara positif mempengaruhi prestasi organisasi.

Berdasarkan hipotesis di atas, model perkongsian pengetahuan di kalangan pekerja dalam organisasi sektor swasta di Malaysia (MPS) digambarkan dalam Rajah 1. Pemboleh ubah eksogenus adalah pengaruh individu, organisasi dan teknologi. Pemboleh ubah endogenus pula adalah amalan perkongsian pengetahuan. Namun, pada masa yang sama amalan perkongsian pengetahuan bertindak sebagai pemboleh ubah eksogenus kepada inovasi dan prestasi organisasi yang berperanan sebagai pemboleh ubah endogenus. Indikator bagi tiga faktor pengaruh (individu, organisasi,teknologi) adalah berdasarkan kepada komponen yang terdapat dalam tiga teori yang diaplikasikan dalam kajian iaitu SCT, INT dan AST. Tiga indikator bagi pengaruh individu adalah rangkaian sosial, berkongsi visi dan matlamat dan kepercayaan antara pekerja. Indikator bagi pengaruh organisasi adalah tugas saling bergantungan, sokongan pengurusan atasan dan budaya organisasi. Manakala, tiga indikator bagi pengaruh teknologi adalah kesetiaan, konsensus dan sikap individu terhadap penggunaan KMS untuk berkongsi pengetahuan dalam organisasi.

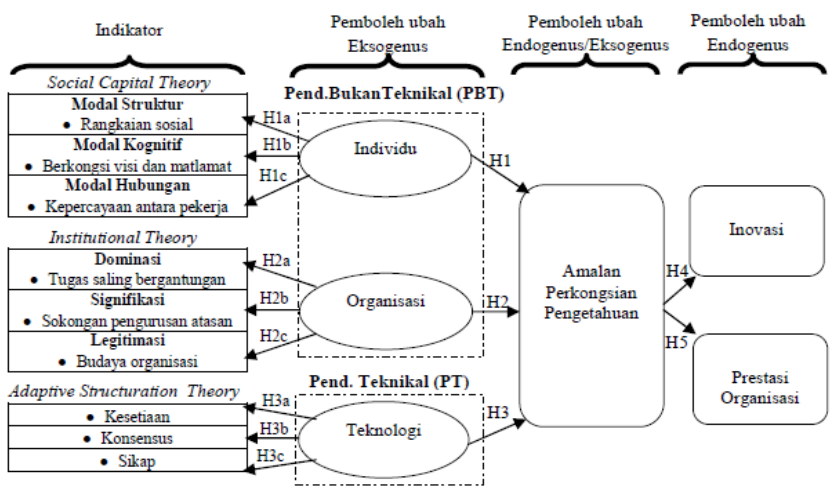

Rajah 1 Model perkongsian pengetahuan sektor swasta (MPS) 


\subsection{METODOLOGI KAJIAN}

Kajian ini menggunakan 'kaedah campuran' ataupun mix method yang merupakan kombinasi pendekatan kualitatif dan pendekatan kuantitatif. Tinjauan literatur menunjukkan sangat sedikit penyelidik yang menggunakan kaedah campuran dalam kajian perkongsian pengetahuan (Pham, 2008). Gabungan berbagai pemerhatian, teori, kaedah dan bahan empirikal dalam kaedah campuran dapat mengatasi kelemahan atau mengurangkan prasangka dan masalah yang datang daripada satu kaedah tunggal. Teknik yang dipilih bagi mengumpul data kuantitatif adalah teknik soal selidik manakala kualitatif menggunakan teknik temu bual. Teknik temu bual bertindak sebagai pelengkap kepada teknik soal selidik bagi memberi ruang kepada responden untuk berkongsi sebanyak mungkin maklumat yang tidak dapat dinyatakan melalui teknik soal selidik.

Instrumen kajian yang pertama dijalankan adalah mereka bentuk dan membangunkan soal selidik. Pembangunan soal selidik bagi kajian ini dilaksanakan mengikut Skema Lazarsfeld (Lazarsfeld Scheme). Skema Lazersfeld digunakan bagi mengukur konsep yang kadangkala dikenali sebagai "descending the ladder of abstraction" (Lazarsfeld, 1955). Skema ini melibatkan empat peringkat iaitu peringkat bayangan konsep, spesifikasi konsep, pemilihan indikator dan pembinaan indeks yang bermula dari konsep abstrak sehinggalah kepada konsep sebenar. Struktur soal selidik dibahagikan kepada dua iaitu soal selidik berstruktur/tertutup dan soal selidik tidak berstruktur/terbuka. Soal selidik tertutup dipilih kerana soalan yang kemukakan diserta dengan jawapan, manakala soalan berbentuk terbuka dimasukkan diakhir soal selidik bagi membolehkan responden memberi komen kepada sebarang aspek secara terbuka (Sekaran, 2005).

Borang soal selidik mengandungi 6 bahagian yang dibahagikan kepada 2 seksyen utama iaitu Bahagian A yang berkaitan dengan Profil Demografi dan Bahagian B hingga Bahagian $\mathrm{F}$ yang berkaitan dengan pemboleh ubah bagi menguji hipotesis. Bahagian A adalah berkenaan latar belakang responden iaitu jantina, umur, taraf pendidikan, jawatan dan tahun pengalaman kerja dalam organisasi. Selain itu, Bahagian A juga mengandungi soalan tentang jenis industri yang dijalankan oleh organisasi serta KMS yang digunakan untuk berkongsi pengetahuan di kalangan pekerja dalam organisasi. Bahagian $\mathrm{B}$ mengandungi soalan berkaitan amalan perkongsian pengetahuan di kalangan pekerja dalam organisasi seperti kesediaan responden untuk menyumbang pengetahuan kepada rakan dan kemampuan responden untuk mengumpul pengetahuan daripada rakan mereka. Bahagian $\mathrm{C}$ adalah soalan berkaitan pendekatan teknikal yang merujuk kepada pengaruh teknologi. Manakala Bahagian D dan Bahagian $\mathrm{E}$ adalah berkenaan pendekatan bukan teknikal yang merujuk kepada pengaruh individu dan pengaruh organisasi dalam perkongsian pengetahuan. Akhir sekali, Bahagian F mengandungi soalan berbentuk terbuka bagi membolehkan responden memberi komen kepada sebarang aspek berkenaan perkongsian pengetahuan. Semua item dalam Bahagian B hingga Bahagian E diukur menggunakan Skala Likert 5 skala, bermula daripada skala 1 (Sangat Tidak Bersetuju) hingga skala 5 (Sangat Bersetuju). Skala Likert dipilih kerana mempunyai beberapa kelebihan seperti mudah diurus dan dipakai, item mudah dijawab oleh responden dan data yang dipungut mempunyai kebolehpercayaan yang tinggi berbanding skala lain seperti Thurstone dan Guttman (Chua, 2009).

Kebolehpercayaan instrumen telah diuji melalui kajian rintis ke atas 50 orang responden dan keputusan ujian kebolehpercayaan bagi setiap pemboleh ubah adalah seperti di Jadual 3. Semua pemboleh ubah mempunyai alpha Cronbach melebihi 0.70 . Menurut Nunnaly (1978) dan Pallant (2001), pekali Cronbach alpha yang melebihi 0.7 adalah boleh dipercayai dan diterima. Ini menunjukkan kesemua kriteria penilaian dan item dalam soal selidik mempunyai tahap kebolehpercayaan yang tinggi dan sesuai untuk mengukur konsep. Ujian kesahan soal selidik dilakukan dengan mendapat pandangan dan komen daripada tujuh orang pakar yang terdiri daripada dua orang pensyarah dalam bidang pengurusan pengetahuan serta lima orang pengurus kanan di lima organisasi sasaran responden. Dua ujian kesahan yang dilakukan adalah ujian kesahihan kandungan dan ujian kesahihan muka. Kedua-dua ujian dilaksanakan untuk membolehkan pakar mengesahkan pengukuran yang digunakan mengukur apa yang sepatutnya diukur (Ramayah, 2008). Semua komen yang diberikan oleh pakar telah diambil kira bagi menambah baik borang soal selidik.

Kajian ini melibatkan responden di lima syarikat swasta sekitar Lembah Klang dan Selangor. Populasi terdiri daripada pegawai pengurusan kerana 'pegawai pengurus memainkan peranan penting dalam proses penciptaan pengetahuan organisasi' (Nonaka dan Takeuchi, 1995). Kaedah pensampelan rawak mudah digunakan kerana sesuai bagi populasi individu yang ramai dalam organisasi yang berbeza serta mengelak berlakunya bias (Sekaran, 2010). Saiz sampel ditentukan dengan menggunakan 'Small Sampel Technique’ (Krejcie dan Morgan, 1970). Justeru, borang soal selidik diedarkan kepada 582 responden dan sebanyak 323 $(55.5 \%)$ borang soal selidik telah dikembalikan dan didapati boleh diguna untuk analisis. Seterusnya, temu bual mendalam secara semi-struktur dilakukan ke atas sepuluh responden yang terdiri daripada dua wakil bagi setiap organisasi.

Jadual 3 Keputusan ujian kebolehpercayaan

\begin{tabular}{ccc}
\hline Pemboleh ubah & $\begin{array}{c}\text { Item/ } \\
\text { Bilangan } \\
\text { Soalan }\end{array}$ & $\begin{array}{c}\text { Pekali } \\
\text { Cronbach } \\
\text { Alpha }\end{array}$ \\
\hline $\begin{array}{c}\text { Amalan perkongsian } \\
\text { pengetahuan }\end{array}$ & 7 & 0.912 \\
Kesetiaan & 5 & 0.874 \\
Konsensus & 5 & 0.711 \\
Sikap & 5 & 0.874 \\
Rangkaian sosial & 5 & 0.734 \\
Kepercayaan antara pekerja & 5 & 0.876 \\
Berkongsi visi dan matlamat & 5 & 0.916 \\
Budaya organisasi & 6 & 0.864 \\
Sokongan pengurusan atasan & 5 & 0.896 \\
Tugas saling bergantungan & 5 & 0.835 \\
Inovasi & 5 & 0.850 \\
Prestasi organisasi & 5 & 0.771 \\
\hline
\end{tabular}

\subsection{ANALISIS DAN KEPUTUSAN}

Data dianalisis menggunakan Statistical Package for the Social Sciences (SPSS) bagi analisis deskriptif dan analisis demografi, manakala model disahkan menggunakan analisis Structural Equation Modelling (SEM). Kajian mendapati, pengaruh individu yang terdiri daripada faktor 'berkongsi visi dan matlamat' dan 'kepercayaan antara pekerja' mempengaruhi amalan perkongsian pengetahuan. Faktor lain yang didapati mempengaruhi amalan perkongsian pengetahuan dalam organisasi sektor swasta adalah 'tugas saling bergantungan' dan 'sokongan pengurusan atasan' bagi pengaruh organisasi dan 'kesetiaan' menggunakan KMS bagi pengaruh teknologi. Keseluruhan hasil analisis SEM Model MPS bagi kajian ini adalah seperti di tunjukkan dalam Rajah 2 dan Jadual 4. 


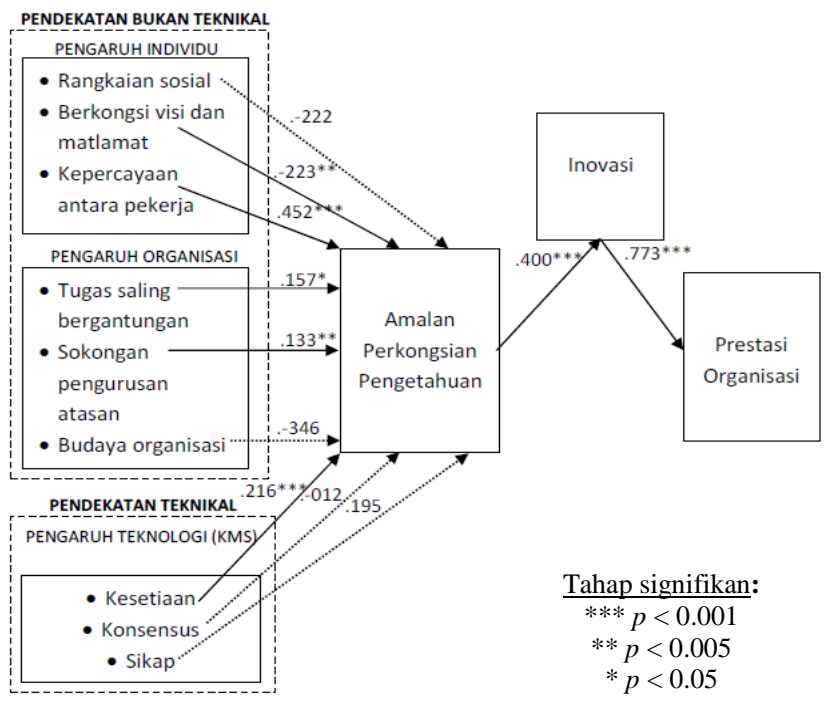

Rajah 2 Hasil analisis SEM model MPS

Jadual 4 Hipotesis kajian model MPS

\begin{tabular}{|c|c|c|c|}
\hline & $\boldsymbol{\beta}$ & C.R & $p$ \\
\hline $\begin{array}{l}\text { Amalan perkongsian pengetahuan }<-- \\
\text { Rangkaian sosial }\end{array}$ & -0.222 & -1.344 & .179 \\
\hline $\begin{array}{l}\text { Amalan perkongsian pengetahuan }<-- \\
\text { Berkongsi visi dan matlamat }\end{array}$ & -0.223 & -2.415 & .016 \\
\hline $\begin{array}{l}\text { Amalan perkongsian pengetahuan }<-- \\
\text { Kepercayaan antara pekerja }\end{array}$ & 0.452 & 3.552 & $* * *$ \\
\hline $\begin{array}{l}\text { Amalan perkongsian pengetahuan }<-- \\
\text { Tugas saling bergantungan }\end{array}$ & 0.157 & 2.004 & .045 \\
\hline $\begin{array}{l}\text { Amalan perkongsian pengetahuan }<-- \\
\text { Sokongan pengurusan atasan }\end{array}$ & 0.133 & 1.988 & .047 \\
\hline $\begin{array}{l}\text { Amalan perkongsian pengetahuan }<-- \\
\text { Budaya organisasi }\end{array}$ & -0.346 & -1.933 & .053 \\
\hline $\begin{array}{l}\text { Amalan perkongsian pengetahuan }<-- \\
\text { Kesetiaan }\end{array}$ & 0.216 & 3.907 & $* * *$ \\
\hline $\begin{array}{l}\text { Amalan perkongsian pengetahuan }<-- \\
\text { Konsensus }\end{array}$ & -0.012 & -0.103 & 0.918 \\
\hline $\begin{array}{l}\text { Amalan perkongsian pengetahuan }<-- \\
\text { Sikap }\end{array}$ & 0.195 & 1.349 & 0.177 \\
\hline $\begin{array}{l}\text { Inovasi < -- Amalan perkongsian } \\
\text { pengetahuan }\end{array}$ & 0.400 & 5.347 & $* * *$ \\
\hline Prestasi organisasi < -- Inovasi & 0.773 & 7.353 & $* * *$ \\
\hline
\end{tabular}

Hasil analisis mendapati amalan perkongsian pengetahuan mempunyai hubungan yang signifikan dengan inovasi dan inovasi mempunyai hubungan yang signifikan ke atas prestasi organisasi. Dapatan ini menunjukkan bahawa inovasi telah bertindak sebagai mediator bagi hubungan di antara amalan perkongsian pengetahuan dengan prestasi organisasi. Berdasarkan Jadual 5, empat daripada tujuh indeks fit memenuhi julat nilai yang ditetapkan. Sebagaimana disarankan oleh Hair et al. (2010), jika tiga atau empat indeks diterima sudah memadai bagi menunjukkan kesesuaian model. Justeru, pembentukan model MPS adalah sesuai dan diterima.
Jadual 5 Indeks kesesuaian model MPS

\begin{tabular}{|c|c|c|c|}
\hline $\begin{array}{c}\text { Ukuran } \\
\text { kesesuaian }\end{array}$ & $\begin{array}{l}\text { Nilai yang ditetapkan untuk } \\
\text { kajian ini }\end{array}$ & $\begin{array}{c}\text { Dapatan } \\
\text { nilai } \\
\text { ukuran }\end{array}$ & Rumusan \\
\hline Nilai $\chi^{2}$ & Tidak signifikan $\mathrm{p}>0.05$ & $\begin{array}{c}\text { Signifikan } \\
\mathrm{P}=0.000\end{array}$ & $\begin{array}{c}\text { Tidak } \\
\text { diterima }\end{array}$ \\
\hline$\chi^{2} / \mathrm{df}$ & $\begin{array}{l}<3.0 \text { (Medsker et al. } 1994, \\
\text { Loo 1999) }\end{array}$ & 1.905 & Diterima \\
\hline GFI & $\geq 0.80$ (Doll et al. 1994) & .835 & Diterima \\
\hline AGFI & $\begin{array}{l}\geq 0.80 \text { (Doll et al. } 1994, \\
\text { Gefen } \text { et al. } 2000)\end{array}$ & .811 & Diterima \\
\hline NFI & $\begin{array}{l}\geq 0.80 \text { (Bentler \& Bonett, } \\
1980 \text { ) }\end{array}$ & .792 & $\begin{array}{c}\text { Tidak } \\
\text { Diterima }\end{array}$ \\
\hline CFI & $\geq 0.90$ (Hu \& Bentler, 1995) & .888 & $\begin{array}{c}\text { Tidak } \\
\text { Diterima }\end{array}$ \\
\hline RMSEA & $<0.10($ Hair et al. 2010) & .053 & Diterima \\
\hline
\end{tabular}

\subsection{SUMBANGAN DAN BATASAN}

Dari segi teori, kajian ini secara signifikan telah menyumbang kepada bidang pengurusan pengetahuan amnya dan perkongsian pengetahuan khususnya. Manakala sumbangan lain adalah; Pertama, kajian ini telah membuka ruang kepada pelbagai teori baru dalam perkongsian pengetahuan. Model MPS dibangun berdasarkan kepada Teori Strukturasi (Structuration Theory) dan teori-teori terbitannya iaitu Social Capital Theory, Institutional Theory dan Adaptive Structuration Theory. Ketiga-tiga teori digabungkan bagi memeriksa tiga faktor pengaruh yang dikaji iaitu individu, organisasi dan teknologi. Gabungan tiga teori dengan tiga faktor pengaruh dalam satu model telah menghasilkan model perkongsian pengetahuan yang lengkap dan menyeluruh dalam sebuah organisasi.

Kedua, Model MPS yang dibangunkan adalah menyeluruh kerana telah menggabungkan dua pendekatan utama perkongsian pengetahuan iaitu PT dan PBT. Kedua-dua pendekatan ini terbukti berkesan kerana melibatkan faktor manusia iaitu pekerja yang mencipta dan berkongsi pengetahuan dalam organisasi dan faktor teknologi bagi memudah dan mempercepatkan lagi proses perkongsian pengetahuan di kalangan pekerja. Penemuan ini membolehkan pengurusan tertinggi yang berminat untuk mempraktikkan amalan perkongsian pengetahuan dalam organisasi memberi tumpuan kepada dua pendekatan ini kerana kedua-duanya sangat penting dan tidak boleh diabaikan.

Ketiga, jika dibandingkan dengan kajian terdahulu, kajian ini tidak hanya terbatas kepada faktor yang mempengaruhi amalan perkongsian pengetahuan sahaja, tetapi juga memeriksa kesan amalan perkongsian pengetahuan di kalangan pekerja dalam organisasi ke atas inovasi dan prestasi organisasi. Hubungan antara amalan perkongsian pengetahuan dengan inovasi dan prestasi organisasi adalah satu sumbangan teori kepada pengetahuan yang belum diuji secara empirikal terutamanya di Malaysia.

Batasan kajian ini adalah pada skop penyelidikan yang hanya tertumpu kepada perkongsian pengetahuan dalam organisasi sektor swasta di Malaysia. Kajian seharus dipanjangkan kepada perkongsian pengetahuan dalam organisasi sektor awam. Hasil kajian daripada kedua-dua organisasi sektor awam dan sektor swasta boleh dibandingkan untuk melihat tahap keberkesanan perkongsian pengetahuan dalam kedua-dua organisasi. Keputusannya boleh digunakan untuk membantu organisasi meningkatkan amalan perkongsian pengetahuan bagi memperolehi manfaat perkongsian pengetahuan dalam usaha meningkatkan prestasi organisasi. 


\subsection{KESIMPULAN DAN PENYELIDIKAN MASA} DEPAN

Menyedari kepentingan perkongsian pengetahuan sebagai sebahagian daripada faktor kejayaan kritikal (critical success factors-CSF) bagi pelaksanaan pengurusan pengetahuan dalam sebuah organisasi, kajian ini membangunkan sebuah model perkongsian pengetahuan di kalangan pekerja dalam organisasi sektor swasta di Malaysia yang mengintegrasikan dua pendekatan utama perkongsian pengetahuan iaitu PT dan PBT.

Model perkongsian pengetahuan sektor swasta (MPS) yang dibangunkan adalah komprehensif kerana menerangkan perkongsian pengetahuan di kalangan pekerja dalam sebuah organisasi secara menyeluruh dengan menggabungkan Social Capital Theory, Institutional Theory dan Adaptive Structuration Theory bagi memeriksa tiga faktor pengaruh iaitu individu, organisasi dan teknologi.

Dapatan menunjukkan amalan perkongsian pengetahuan di kalangan pekerja dalam organisasi mempengaruhi inovasi kerana pekerja menjadi lebih kreatif, memperoleh idea baru untuk meningkatkan proses kerja serta mencari kaedah baru dalam melaksanakan tugas. Seterusnya, peningkatan inovasi di kalangan pekerja mempengaruhi prestasi organisasi dari segi menjimatkan masa operasi, mengurangkan kos pengurusan serta meningkatkan kualiti dan produktiviti. Kajian mendapati bahawa, inovasi telah bertindak sebagai mediator bagi hubungan di antara amalan perkongsian pengetahuan dengan prestasi organisasi.

\section{Rujukan}

Alavi, M. and Leider, D. 2001, Review: Knowledge Management and Knowledge Management Systems: Conceptual Foundations and Research Issues. MIS Quarterly. 25(1): 107-136.

Andrew H. G., Arvind M., Segars H. A. 2001. Knowledge Management: An Organization Capabilities Perspective. Journal of Management Information System. 18(1): 185-214.

Burt, R. S. 1992. Structural Holes: The Social Structure of Competition. Harvard University Press, Cambridge, MA

Chatterjee, D.D., Pacini, C., and Sambamurthy, V. 2002. The ShareholderWealth and Trading-Volume Effects of Information-Technology Infrastructure Investments. Journal of Management Information Systems. 19(2): 7-42.

Chin, W. W., Gopal, A. and Salisbury, W. D. 1997. Advancing the Theory of Adaptive Structuration: The Development of a Scale to Measure Faithfulness of Appropriation. Information Systems Research. 8(4): 342367.

Chua, Y. P. 2009. Advanced Research Statistics: Univariate and Multivariate Tests. Shah Alam: McGraw-Hill Education.

Chow, W. S., \& Chan, L. S. 2008. Social Network, Social Trust and Shared Goals in Organizational Knowledge Sharing. Information \& Management. 45(7): 458-465.

Chowdhury, S. 2005. The Role of Affect-and Cognition-based Trust in Complex Knowledge Sharing. Journal of Managerial Issues. 17(3): 310-326.

Coleman, J. S. 1990. Foundation of Social Theory. Belknap/Harvard University Press, Cambridge, MA

Coleman, D. (1999), 'Groupware: Collaboration and knowledge sharing', in Liebowitz, J. Knowledge management handbook. Boca Raton: CRC Press.

Connelly, C. E. and Catherine, E. K. 2002. Predictors of Employees' Perceptions of Knowledge Sharing Cultures. Leadership and Organization Development Journal. 24(5): 294-301.

Davis, F. D. 1989. Perceived Usefulness, Perceived Ease of Use, and User Acceptance of Information Technology. MIS Quarterly. 13(3): 319-339.

DeSanctis, Gerardine and M.Scott Poole. 1994. Capturing the Complexity in Advanced Technology Use: Adaptive Structuration Theory. Organization Science. 5(2): 121-147.

Disterer, G. 2001. Individual and Social Barriers to Knowledge Transfer. [Online] [Retrieved Disember 12, 2011] from:http://www.hicss.hawaii.edu.

Elliott, S. and O'Dell, C. 1999. Sharing Knowledge and Best Practices: The Hows and Ways of Tapping Your Organization's Hidden Reservoirs of Knowledge. Health Forum Journal. 42(3): 34-37.
Fan, Z. P., Ou, W., Suo, W. L. and Sun, Y. H. 2008. Measuring and Identifying Knowledge Sharing Capability of Organizations. In Proceeding of the International Conference on Wireless Communications, Networking and Mobile Computing. 21-25 September 2008, Shanghai, China.

Gibbert, M. and Krause, H. 2002. Practice Exchange in a Best Practice Marketplace. In Knowledge Management Case Book: Siemen Best Practices, Davenport, T. H and Probst, G.J.B. (eds.). Publicis Corporate Publishing, Erlangen, Germany.

Hair, J. F., Black, W. C., Babin, B. J., \& Anderson, R. E. 2010. Multivariate Data Analysis. Seventh Edition. Prentice Hall, Upper Saddle River, New Jersey.

Hall, H. 2002. Sharing Capability: The Development of a Framework to Investigate Knowledge Sharing in Distributed Organizations. In Proceedings of the Third European Conference on Organizational Knowledge, Learning and Capabilities. 5-6 April 2002, Athens, Greece.

Hartini, A., Normala, S. and Harom, C. S. 2006. Knowledge Sharing Behavior in the Public Sector: The Business Process Management Perspectives. In Knowledge Management International Conference and Exhibitions (KMICe). 6-8 June 2006, Kuala Lumpur, Malaysia.

Hsu, I. 2008. Knowledge Sharing Practices as a Facilitating Factor for Improving Organizational Performance Through Human Capital: A Preliminary Test. Expert Systems with Application. 35(3): 1316-1326.

Inkpen, A. C. and A. Dinur. 1998. Knowledge Management Processes and International Joint Ventures. Organization Science. 9(4): 454-468.

Johnson, G., Scholes, K., Whittington, R. 2005. Exploring Corporate Strategy. 8th ed. Harlow: Pearson Education Limited. 215-557.

Kankanhalli, A., Tan, B. C. Y., and Wei, K. K. 2005. Contributing Knowledge to Electronic Knowledge Repositories: An Empirical Investigation. MIS Quarterly. 29(1): 113-143.

Katz, E. and Lazarsfeld, P. F. 1955. Personal Influence: The Part Played by People in the Flow of Mass Communications. New York: Free Press.

Kementerian Sains, Teknologi dan Inovasi (MOSTI). Laporan Pameran Malaysia Inovatif 2010

Lee, C. K. and Al-Hawamdeh, S. 2002. Factors Impacting Knowledge Sharing. Journal of Information and Knowledge Management. 1 (1): 49-56.

Lee, H. \& Choi, B. 2003. Knowledge Management Enablers, Processes, and Organizational Performance: An Integrative View and Empirical Examination. Journal of Management Information System. 20 (1): 179228.

Lee, J., Kim, J. and Han, Y. 2010. A Study on Factors Influencing Knowledgesharing Activity for the Innovation Activity of Team. In IEEE International Conference on Advanced Management Science (ICAMS). 911 July 2010, Seoul, South Korea.

Leonard, D. 1995. Wellsprings of Knowledge, Building \& Sustaining the Sources of Innovation. Harvard Business School Press, Boston, MA.

Levinthal, D., March, J. 1993. The Myopia of Learning. Strategic Management Journal. 14(1): 95-13.

Liang T. P., Liu C. C. \& Wu, C. H. 2008. Can Social Exchange Theory Explain Individual Knowledge Sharing Behavior? A Meta-analysis. Retrieved from http://www.whiceb.com/download/whiceb2008/seminar/TingPeng\%20Liang.pdf.

Lin, H. F. 2007. Knowledge Sharing and Firm Innovation Capability: An Empirical Study. International Journal of Manpower. 28(3): 315-332.

Lin, H. F. and Lee, G. G. 2004. Perceptions of Senior Managers Toward Knowledge-sharing Behavior. Management Decision. 42(1): 108-25.

Ling, W. C., Sandhu, M. S., \& Jain, K. M. 2009. Knowledge Sharing in an American Multinational Company Based in Malaysia. Journal of Workplace Learning. 21(2): 125-142.

Lodhi, S. A. 2005. Culture Based Knowledge Sharing Model. PhD thesis, National College of Business Administration \& Economics, Lahore, Pakistan

Low, H. H., Omain, S. Z. \& Md Som, H. 2000. Perkongsian Pengetahuan d Kalangan Industri Kecil dan Sederhana. Laporan Penyelidikan. Fakulti Pengurusan dan Pembangunan Sumber Manusia Universiti Teknologi Malaysia.

Mohamed and Egbu. 2010. Issues Associated with Knowledge Sharing Initiatives in Government Agencies in Malaysia' in CIB World Congress 2010. 10-13 May 2010, The Lowry, Salford Quays, United Kingdom.

Mohd Bakhari, I. 2010. Model Kualiti Perkongsian Pengetahuan Dalam Organisasi Awam dan Kesannya ke atas Pekerja serta Penyampaian Perkhidmatan. PhD Thesis, Universiti Kebangsaan Malaysia, Bangi, Selangor.

Mohd Bakhari, I. and Zawiyah M. Y. 2008. Factors Affecting Knowledge Sharing in Public Organizations in Malaysia. In Knowledge Management International Conference and Exhibitions (KMICe).

M.Sadiq and Salina. 2009. Knowledge Sharing in Higher Education Institutions: Perspective from Malaysia. The Journal of Information and Knowledge Management System. 39(2): 125-142. 
Nahapiet, J. and Ghoshal, S. 1998. Social Capital, Intellectual Capital, and the Organizational Advantage. The Academy of Management Review. 23(2): 242-266.

Nonaka, I. and Takuechi, H. 1995. The Knowledge-Creating Company: How Japanese Companies Create the Dynamics of Innovation. New York: Oxford University Press.

Norizah Supar, Azizi Ali Ibrahim, Zainal Abidin Mohamed, Mastura Yahya and Mohani Abdul. 2005. Factors Affecting Knowledge Sharing and Its Effect on Performance: A Study of Three Selected Higher Academic Institutions. In International Conference on Knowledge Management (ICKM).

Nurliza, Unchenna and Gerald. 2010. Keys Determinants of Knowledge Sharing in an Electronics Manufacturing Firms in Malaysia. Library Review. 60(1): 53-67.

O’Dell, C. and Grayson, C. J. 1998. If Only We Knew What We Know: Identification and Transfer of Internal Best Practice. Journal of Human Resource Costing and Accounting. 3(1): 83-92.

Orlikowski, W. and Robey, D. 1991. Information Technology and the Structuring of Organizations. Information Systems Research. 2(2): 143169.

Pham-Giat, T. 2008. The Multivariate Selberg Beta Distribution and Applications. Statistics. 43(1): 65-79.

Riege, A. 2005. Three-dozen Knowledge Sharing Barriers Managers Must Consider. Journal of Knowledge Management. 9(3): 18-35.

Roberts, J. 2000. From know-how to show-how? Questioning the Role of Information and Communication Technologies in Knowledge Transfer. Technology Analysis and Strategic Management. 12(4): 429-43.

Rubenstein-Montano, R., Liebowitz, J., Buchwalter, J., and Mcgraw, D. 2000. A Systems Thinking Framework for Knowledge Management. Decision Support Systems. 31(1): 5-6.

Salisbury, W. D., Chin, W. W., Gopal, A. and Newsted, P. R. 2002. Research Report: Better Theory Through Measurement in Developing a Scale to Capture Consensus on Appropriation. Information System Research. 13(1): 91-103.

Sharratt, M. and Usoro, A. 2003. Understanding Knowledge-sharing in Online Communities of Practice. Electronic Journal on Knowledge Management 1(2): 187-196.

Skyrme, D. J. 2002. The 3Cs of Knowledge Sharing:Culture, Co-opetition and Commitment. [Online]Retrieved June 11, 2011] http://www.skyrme.com/updates/u64_f1.htm.
Smircich, L. 1983. Concepts of Culture and Organizational Analysis. Administrative Science Quarterly. 28(3): 339-358.

Song, Z-Hong, Fan, L-B and Chen, S. 2008. Knowledge Sharing and Innovation Capability:

Does Absorptive Capacity Function as a Mediator? In International Conference on Management Science \& Engineering (15th). 10-12 September 2008 , Long Beach, USA.

Sveiby. 2001. A Knowledge-based Theory of the Firm to Guide in Strategy Formulation. Journal of Intellectual Capital. 2 (4): 344-358.

Syed Ikhsan, S.O.S. and F. Rowland. 2004. Benchmarking Knowledge Management in a Public Organisation in Malaysia. Benchmarking: An International Journal. 11(3): 238-266.

Tsai, M.-T., Chang, H.-C., Cheng, N.-C. and Lien, C.-C. 2012. Understanding IT Professionals' Knowledge Sharing Intention Through KMS: A Social Exchange Perspective. Quality \& Quantity. 3 March 2012, 1-15.

Wageman, R. and Baker, G. 1997. Incentives and Cooperation: The Joint Effects of Task and Reward Interdependence on Group Performance. Journal of Organizational Behavior. 18(2): 139-158.

Wang, Fang Hua. 1999. Knowledge Management. 1st.ed. China: Economy Shan Xi Publisher.

Wang, Da Hai, Yang, Du \& Chai, Jing Kui. 2000. Xing Shi Ji De Ying Jia', 1st.ed. Beijing: Xue Yuan Publisher.

Wasko, M. M. and Faraj, S. 2005. Why Should I Share? Examining Social Capital and Knowledge Contribution in Electronic Networks of Practice. MIS Quarterly. 29(1): 35-47.

Yasar F. Jarrar. 2002. Knowledge management: learning for organisational experience. Managerial Auditing Journal. 17(6): 322- 28.

Yu, A. Y. and Khalifa, M. 2007. A Conceptual Model for Enhancing Intra-Group Knowledge Sharing. City University of Hong Kong, China . Sprouts: Working Papers on Information Systems. 7(15).

Yu, Z., Yanfei, W., and Hailin, L. 2007. Innovative Capabilities in the Process of Knowledge Sharing to Firm Performance. In International Conference Wireless Communications, Networking and Mobile Computing.

Zand, D. E. 1972. Trust and Managerial Problem Solving. Administration Science Quarterly 17. 229-39.

Zhang, J., Faerman, S. R. and Cresswell, A. M. 2006. The Effect of Organizational/technological Factors and the Nature of Knowledge on Knowledge Sharing. [Online] [Retrieved September 12, 2011], http://www.hicss.hawaii.edu. 